\title{
REGIONAL DEVELOPMENT AND
}

INSTITUTIONAL ENVIRONMENT:

REGIONAL EXPANSION OF FRANCHISE

CHAINS IN BRAZIL

\author{
PEDRO L. R. MELO 1 \\ (iD) https://orcid.org/0000-0002-5947-6279 \\ RENATA T. DELGADO² \\ (iD) https://orcid.org/0000-0002-9543-2820 \\ VICTOR S. CORRÊA ${ }^{1}$ \\ (iD) https://orcid.org/0000-0001-7412-2375 \\ FELIPE M. BORINI ${ }^{3}$ \\ (iD) https://orcid.org/0000-0003-1389-136X
}

To cite this paper: Melo, P. L. R., Delgado, R. T., Corrêa, V. S., \& Borini, F. M. (2020). Regional development and institutional environment: Regional expansion of franchise chains in Brazil. Revista de Administração Mackenzie, 21(5), 1-30. doi:10.1590/1678-6971/eRAMR200088

Submission: May 6, 2019. Acceptance: Apr. 28, 2020.

1 Paulista University (Unip), São Paulo, SP, Brazil.

2 Paulista University (Unip), Santana de Paranaíba, SP, Brazil.

3 University of São Paulo (USP), São Paulo, SP, Brazil.

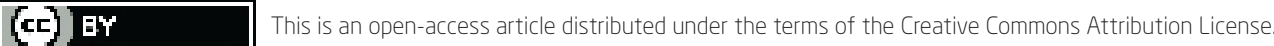

\footnotetext{
This paper may be copied, distributed, displayed, transmitted or adapted if provided, in a clear and explicit way, the name of the journal, the edition, the year and the pages on which the paper was originally published, but not suggesting that RAM endorses paper reuse. This licensing term should be made explicit in cases of reuse or distribution to third parties. It is not allowed the use for commercial purposes.

Este artigo pode ser copiado, distribuído, exibido, transmitido ou adaptado desde que citados, de forma clara e explícita, o nome da revista, a edição, o ano e as páginas nas quais o artigo foi publicado originalmente, mas sem sugerir que a RAM endosse a reutilização do artigo. Esse termo de licenciamento deve ser explicitado para os casos de reutilização ou distribuição para terceiros. Não é permitido o uso para fins comerciais.
} 


\section{ABSTRACT}

Purpose: This paper aims to analyze the attractiveness of the markets in the inland of Brazil to franchise chains based on the characteristics of institutional environment, referring to the socioeconomic, geographical, and human resources dimensions.

Originality/value: Interiorization is a theme that has been hardly explored in franchise chains' growth strategies. This paper contributes to this debate through the institutional theoretical perspective, contributing to the clarification and ordering of the decision-making factors for the regional expansion of franchises. For regional development, it calls for municipal management to direct actions aimed at socioeconomic development and human resources.

Design/methodology/approach: The quantitative method using secondary data - from Brazilian Association of Franchising (Associação Brasileira de Franchising $[\mathrm{ABF}]$ ), Brazilian Association of Shopping Centers (Associação Brasileira de Shopping Centers [Abrasce]), Brazilian Institute of Geography and Statistics (Instituto Brasileiro de Geografia e Estatística [IBGE]) and Google Maps - was employed in this study for the analysis of franchise location and for municipalities. The sample comprised 458 municipalities with a population of above 50 thousand inhabitants. The statistical techniques used were factor analysis and multiple regression analysis.

Findings: The results show that the socioeconomic and human resources factors of the municipalities are essential for the attractiveness of franchises chains to the inland of the country. In turn, the geographical distance of the inland municipality in relation to the state capital did not present adherence to the model as an explanation for the attraction of franchises.

\section{KEYWORDS}

Franchise chains. Institutional environment. Regional development. Interiorization. Entrepreneurship. 


\section{INTRODUCTION}

Brazil has 4,619 municipalities located in the interior, which can be described as cities that are neither state capitals nor part of metropolitan regions. This corresponds to $49 \%$ of the Brazilian population (94.3 million inhabitants) and represents a family income of BRL 827 billion annually (Data Popular, 2014). According to Associação Brasileira de Franchising (2017), in 5,570 Brazilian municipalities, 2,321 have franchise chains units, which correspond to more than $40 \%$ of cities with franchise chains. Among the franchise chains associated with Brazilian Association of Franchising (Associação Brasileira de Franchising $[\mathrm{ABF}]$ ), 25\% are in cities in the interior of the country, whereas the remaining $75 \%$ are in capitals and metropolitan regions. These demographic and financial indicators show the consumption potential of regional markets, which can be exploited by franchise chains.

From the perspective of retail ventures, the selection of the location is decisive for its success, and because of this, the concern primarily focuses on places with relevant population concentration (Barringer \& Greening, 1998). This is considered a crucial process when it comes to the expansion of franchise chains. From the 1980s to the 2000s, franchise chains expansion in Brazil concentrated in larger cities, mainly in capitals and regional hubs. Although the expansion strategy for locations with a high population was a priority, some limitations for franchise chains, such as stagnation of the consumer market, high competition, cannibalization between units in the same franchise chain, and high real estate costs may be identified (Moita \& Guerra, 2012). In contrast, smaller cities create opportunities for new ventures and reduce models of franchise chains because of its increased purchasing power and lower level of competition (Moita \& Guerra, 2012; Cunha et al., 2015; Bitti, Aquino, \& Amato, 2010; Portal do Franchising, 2015).

This situation originated the phenomenon of interiorization, characterized by the expansion of franchise chains throughout the country. There are limited studies that portray this theme, but all converge to the understanding that expansion is a market growth strategy and has a limitation in the capacity of regional markets to receive a new venture (Jackson, 2008; Minadeo \& Camargos, 2009; Moita \& Guerra, 2012; Silva et al., 2016). Despite this, the process of selecting these markets is not clear. To fill this gap in the literature, this research aims to address the phenomenon of the franchise chain interiorization. This approach will be based on institutional theory, as studies suggest that institutions can be important precursors to entrepreneurial activities. An institutional perspective helps to structure 
the exploration of how corporate factors influence business activity and shape entrepreneurial behavior throughout the business process (Valdez \& Richardson, 2013). Formal institutional aspects have an impact on regulations and law enforcement, whereas informal aspects have an impact on how society enables businesses to thrive locally (Silva et al., 2016; Félix \& Farah, 2013; Khoury \& Prasad, 2015; Melo, Borini, \& Ogasavara, 2019).

This research has argued that franchise chains prefer regional markets with a favorable institutional structure for business, which is represented by socioeconomic, human, and geographical elements. Therefore, this article aims to analyze the attractiveness of markets in the interior of Brazil for franchise chains by considering the socioeconomic, geographical, and human resources dimensions of the institutional environment. To achieve this objective, a quantitative descriptive research was conducted using secondary data, with a sample of 458 Brazilian municipalities with more than 50 thousand inhabitants. For the analyses, multivariate quantitative techniques of factor analysis were used, followed by a multiple linear regression analysis.

The expected academic contribution of the study is the identification of the characteristics of the institutional environment that propelled the expansion of franchise chains in its domestic market, corresponding to the regional markets in Brazil. This identification presents contributions to studies on the institutional environment for entrepreneurship (Bruton, Ahlstrom, \& Li, 2010; Khoury \& Prasad, 2015), expansion of franchise chains (Jackson, 2008; Minadeo \& Camargos 2009; Moita \& Guerra, 2012; Silva et al., 2016), and geographic expansion to regional markets (Barringer \& Greening, 1998; Amin, 1999; Chung, Chen, \& Hsieh, 2007; Cordeiro et al., 2017).

The present article is structured as follows: the literature review section discusses the theories used referring to franchise chains and institutional environment, followed by the development of hypotheses and the methodology section. The analysis of results will be discussed and, lastly, final considerations that include academic and managerial contributions will be presented.

\section{LITERATURE REVIEW}

\subsection{Institutional theory and entrepreneurship}

Institutions can be defined as the set of rules and norms that shape the way individuals interact in a society. These rules have several characteristics, encompassing both formal rules (constitutions, laws, economic rules, 
property rights, and contracts) and informal rules (values, norms, sanctions, taboos, customs, traditions, and codes of conduct) that shape political, economic, and social issues (North, 1991). Therefore, legislation, contracts, organizations (state, companies, civil society organizations etc.), sanctions, property rights, and cultural norms of behavior would be some of the components that form the institutional environments that reference how economies develop. Hence, institutions help explain the roots of uneven economic development between countries and regions (Lopes, 2013). In this sense, institutionalism can offer an incentive structure to the economy. Additionally, as the institutional structure evolves, it can shape the direction of economic change toward growth, stagnation, or decline.

By informing the "rules of the game" within society, formal institutions define the parameters of the market, resources, and protection of property rights, whereas informal institutions define relational conventions, habits, and customs that allow behavior within business processes (Biggart \& Beamish, 2003; Bathelt \& Gluckler, 2014). Formal institutions are found in political rules, legal decisions, regulatory regime, and economic issues and determine the nature of property rights, access to finance, skills and knowledge development, and employment relationships (Hessels \& Terjesen, 2010; Schwens, Eiche, \& Kabst, 2011). In many developing countries, informal and formal institutions coexist to compensate for the lack of formal institutions and maintain reasonable stability (Khoury \& Prasad, 2015). This notion of informal relations also represents the way in which entrepreneurs survive in a dynamic context, as in the case of economies in transition and, especially, in emerging countries (Steer \& Sen, 2010).

Informal institutional constraints, such as limitations in the interaction between cultures in which gender, ethnicity, family history, or religion governs social exchange systems, occur in relational interactions within and between groups of individuals. Such informal institutional systems can be, according to their own rules, the existing restrictions on institutions (Khoury \& Prasad, 2015). These conditions represent the starting point for the entrepreneur, who must reconcile the characteristics, flaws, and obstacles within the institutional environment to take advantage of opportunities (Peredo \& McLean, 2013; Khoury, Cuervo-Cazurra, \& Dau, 2014).

Research on entrepreneurship within the scope of the institutional environment has focused on how external environmental factors, in combination with personality and gender factors, influence business activities (Bruton et al., 2010; Welter \& Smallbone, 2010). The most analyzed factors are socioeconomic, geographic, and human resources. 
The analysis of socioeconomic factors includes demographic and economic factors. Demographic factors involve investigating the size of the population, which is considered an essential aspect for the dimensioning of the market, and the economic factors help to identify the population's consumption power, which constitutes a relevant indicator of market potential (Baumol, Litan, \& Schramm, 2007).

Geographic factors are part of the intrinsic variables of a region and can impact transport costs, rent values, and labor qualification. This dimension describes how spatial structure can impact economic analysis, producing imperfect competition between regions (Castiglione et al., 2012).

Finally, the analysis of human resources aspects involves the values, aspirations, and qualifications of professionals, whether employees or owners. It is exclusively about the human part because these factors and elements guide the determinant actions of individuals or groups and generate personal and professional progress (Faller \& Almeida, 2014).

\subsection{Regional development}

The regional development process comprises not only economic growth but also social, cultural, environmental, and political factors. This process includes changes in the composition of society and socioeconomic indicators, such as poverty, unemployment, and inequality (Xavier, Inácio, Wittmann, $\&$ Kern, 2013). The main objective of the regional development is to make peripheral and remote regions sustainable and self-sufficient (Muller, 2016). There is a consensus on the existence of a relationship between entrepreneurship and regional development, as the entrepreneur is responsible for introducing new technologies and resources, stimulating employment, and bringing economic growth (Muller, 2016).

In the last decades, the regional development perspective has increased its presence in the academic sphere, since it represents a way of providing competitiveness for a region in the context of globalized markets. The articles specifically address the role of small businesses in peripheral regions, analyzing three issues: 1. economic: relationship between companies; 2. social: characteristics of the social structure; and 3. territorial: local territorial organization (Xavier et al., 2013).

Furthermore, the determination of regional conditions associated with places with great entrepreneurial activity is a relevant and debated topic in the academy. This line of research analyzes how the regional structure and the institutional context can influence entrepreneurial activity (Muller, 2016). 
Studies have identified the impact of the unemployment rate on the attractiveness of entrepreneurial activity, but they are not conclusive as to whether the effect is positive or negative. Another indicator pointed out is the employment structure, as areas with a high proportion of educated and specialized workforce have higher rates of starting a business. Regions dominated by small companies, too, have higher rates of new companies than those dominated by large companies. Additionally, there is the impact of local policies that encourage entrepreneurship, access to financial capital, and the presence of local networks (Muller, 2016; Dan \& Goia, 2018).

Franchise chains have been noted as the key companies for the economy. They have been a driving force for business activities and for the growth of small companies. As small businesses usually lack basic management skills, they are more vulnerable to financial risks and uncertainties, especially when they are not part of a franchise chain. Consequently, franchise chains are a gateway to entrepreneurship, facilitating business success because of the cooperation of the franchisor (Lee et al., 2015).

\subsection{Franchise chains and regional development}

Franchise chains can be defined as a networked system that allows the owner of a company (franchisor) to grow and expand their business by selling units to a third party (franchisee). In addition to the acquisition of the unit, the franchisee will be acquiring the know-how, brand, products, and services developed by the franchisor (Melo et al., 2015). The franchisor, in return, will receive monetary contributions from the franchisee, such as the initial investment and royalties that will maintain the franchise chain, in addition to serving as the payment for tangible and intangible resources (Melo et al., 2015). This business model allows for cost-sharing and rapid market penetration, making it a relevant expansion option for small companies that have scarce or limited resources, whether financial, employeerelated, managerial, or informational (Melo et al., 2015).

Brazilian franchise chains are more concentrated in large urban centers and cities with populations of over 500 thousand inhabitants. Smaller cities, in contrast, have small local merchants who are not competitive with franchise chains. The demand for new brands in these cities and the cannibalization in large cities has guided franchise chains to expand toward the interior of the country (Moita \& Guerra, 2012).

The strategic search of new markets in the municipalities by franchise chains shows that the high capillarity rates achieved in capitals and large 
urban centers limit growth and cause cannibalization (Silva et al., 2016). The large number of points of sale causes spatial competition between geographically close points, which is represented by a new unit that captures similar sales from already-established points. Thus, the expansion strategy, depending on the choice of location, is affected by cannibalization, which can influence the choice of a new location (Silva et al., 2016). To avoid cannibalization, franchise chains have to expand into the interior of the country, in cities that have a potential consumer market, infrastructure resources, distribution logistics, and regional attractiveness (Minadeo \& Camargos, 2009).

\section{HYPOTHESES}

Three research hypotheses were developed to relate the attractiveness of the institutional environment with the geographic expansion of the franchise chains to the markets of the interior of the country. These hypotheses comprise the socioeconomic, geographical, and human resources dimensions as these represent factors of the institutional environment that provide greater attractiveness to business in the municipalities (Silva, Monte-Mór, $\&$ Barbieri, 2012). Figure 3.1 summarizes the research framework.

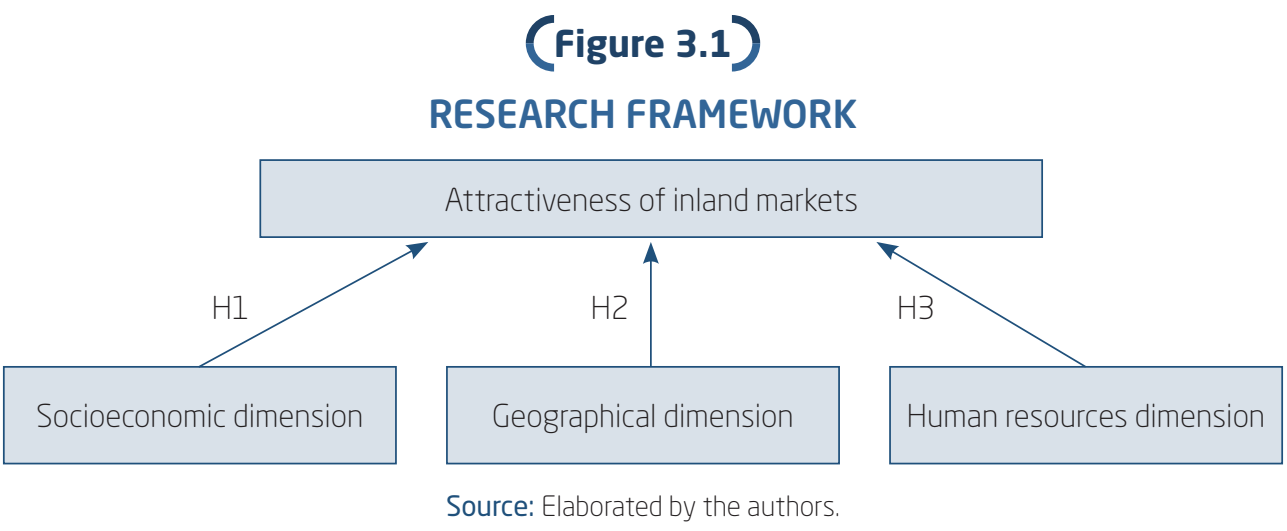

\subsection{Socioeconomic dimension}

The characteristics of a society are affected by its socioeconomic dynamics, depending on how the population changes, not only in absolute size, but also in other aspects, such as age structure, spatial distribution, income distribution, household structure, level of education, and employability (Silva 
et al., 2012). This dimension influences the business environment to the extent that gaining its knowledge enables better financial and marketing management, resulting in better decisions about the business model, product offered, pricing, location, and communication (Cordeiro et al., 2017).

Among the aspects indicated, two stood out: education and income. These aspects directly influence the development and creation of a favorable institutional environment for local businesses, such as influencing consumers' attitudes toward products and brands, and they can be used to segment markets. In addition, specifically related to income, it can be highlighted that, for socioeconomic development, it is essential that the population is employed, as this will result in the consequent reduction of poverty and better social conditions and purchasing power.

In Brazil, income inequality is a major factor that makes poverty alleviation difficult, as the effect of economic growth on poverty reduction is less in Brazil than in other countries with similar per capita income (Cabral \& Araujo, 2015). Additionally, in the case of small Brazilian municipalities, they must find ways to develop economically to reduce the exodus toward large centers. Franchise chains, specifically, are attracted to organized point of sale structures, such as shopping centers. These ventures appear as new consumption spaces that create and recreate new ways to attract consumers. Thus, franchise chains start to grow more with the proliferation of shopping centers and malls, adapting to the lifestyle of cities (Carlos, 2001; Silva \& Gonçalves, 2013; Lee et al., 2015).

Regarding the characteristics of the population profile, municipalities with a large population concentration attract franchise chains. Although these locations have greater income inequality, when added together, a large portion of the population considered to be of low income represents a great business potential (Prahalad, 2006, 2012; Cruz, 2014; Dias \& Hemais, 2015). Based on the preceding insights, the following hypothesis was constructed:

- H1: The higher the indexes of the socioeconomic dimension of the municipalities, the more attractive the municipality is for franchise chains.

\subsection{Human resources dimension}

Human resources represent the workforce of a population, considering only the portion that can effectively generate economic development. Without adequate human resources, sustainable development is not possible. The potential of a region's human resources is not measured by the number of 
people, but by its level of qualification, defined as the ability to turn resources into productivity. For this to occur, an institutional environment that favors the understanding and application of the acquired knowledge is also assumed (Kamakura \& Mazzon, 2016).

The most cited variable in the literature that can impact the level of qualification of human resources is education, as investments in education can improve the performance of human capital and the productivity of workers (Eberhardt \& Lima, 2012; Fonseca, Beltrão, \& Prado, 2013; Paschoalino, Caldarelli, \& Camara, 2016). The theory of human capital developed by Theodore Schultz in 1960 emphasizes the importance of human capital in increasing the levels of productivity. This is because individuals with greater skills and knowledge become more productive, generating a higher level of production and enabling technological innovation. Human capital encompasses the skills and knowledge that, together with personal characteristics and expended efforts, increase the productive possibilities of personal, social, and economic well-being (Fontenele, Moura, \& Leocadio, 2011). This transformation of knowledge into human capital means not only transforming the professional side, but also transforming knowledge with respect to ethics, solidarity, entrepreneurship, and social relations as important parts of professional qualification (Botomé \& Zanelli, 2011).

Because of a lack of incentives to attract companies that generate employment and income in small- and medium-sized cities, qualified people tend to move to other regions in search for better job opportunities. This results in difficulties in finding qualified resources. These cities must seek alternatives for sustainable development. In addition to avoiding economic stagnation and population emptying, sustainable development can attract new ventures, which may see the scarcity of qualified resources as an impediment (Félix \& Farah, 2013).

A key factor for franchise chains is qualified labor, as the productivity of workers is higher. Additionally, the increase in workers' productivity will make them acquire greater purchasing power. With greater income in the region, new products and services can be offered, creating new ventures and employing more workers. This will create a virtuous circle in the municipalities and improve the region's economic and social development and consumption potential (Haddad, 2009; Eberhardt \& Lima, 2012; Fonseca et al., 2013). Thus, the following hypothesis was formulated:

- H2: The higher the human resource dimension indexes of the municipalities, the more attractive the municipality is for franchise chains. 


\subsection{Geographical dimension}

Geographical distance is considered a relevant variable, as it implies a reduction in commercial relations with an increase in distance. The distance is related to the costs of transportation, communication, and reduced control over investment operations by the respective investors. Distance is considered an obstacle by many researchers, as it increases the costs and risks of doing business in a new market. Therefore, distance is not only a geographical separation, but also a cultural, administrative, political, and economic limiter that changes the attractiveness of the regional market (Rodrigues, Bezerra, \& Cavalcante, 2015).

A company can operate in one or more geographical areas, but it should pay attention to local variations and peculiarities, regional structure, population characteristics, and market behavior (Cordeiro et al., 2017). In franchise chains, specifically, the risk of opportunistic behavior and breaking standards by franchisees means that the expansion needs to consider the application of control and monitoring mechanisms. The distant location of capitals and large centers can help in the development of business because of the distance from competition, but it tends to increase the logistical cost and the expenses with monitoring and communication (Moita \& Guerra, 2012; Rodrigues et al., 2015). Therefore, regarding operations and logistics related to the distance of the municipalities from the state capitals and the benefits provided by their structures, the following hypothesis is proposed:

- H3: The shorter the distance between the municipality and the state capital, the more attractive the municipality is for franchise chains.

\section{METHODOLOGY}

The quantitative method of a descriptive character was used in this research (Creswell, 2010). The intention was to describe and explore the characteristics of the studied phenomenon that, in this case, concern the process of expanding franchise chains to the interior of the country.

\subsection{Data collection}

The research aimed to analyze the attractiveness of markets in the interior of Brazil for franchise chains considering the characteristics of the insti- 
tutional environment, referring to the socioeconomic, geographical, and human resources dimensions. For this, secondary data were used in relation to the location of both the franchise chains and those of Brazilian municipalities. Only municipalities with more than 50 thousand inhabitants were selected, because according to Brazilian Institute of Geography and Statistics (Instituto Brasileiro de Geografia e Estatística [IBGE]) (2014), municipalities with fewer inhabitants have restrictions on the development of retail. Additionally, $91.6 \%$ of franchise units are in municipalities with more than 50 thousand inhabitants (ABF, 2017), which is relevant to the sample selection. Also, the Federal District, the state capitals, and metropolitan regions considered by IBGE (2014) were excluded because the purpose of this research lies in understanding the attractiveness of franchise chains in inland markets. Consequently, 458 municipalities were selected for the sample.

The data on the location of the franchise units were collected through the Relatório de desempenho do franchising do ano de 2015 (ABF, 2016). Information regarding the number of franchise units in each Brazilian municipality can be extracted from the report. Conversely, institutional data from Brazilian municipalities (socioeconomic and human resources dimensions) were collected through the Atlas do desenvolvimento humano (Programa das Nações Unidas para o Desenvolvimento [Pnud], 2013). Figure 4.1.1 shows the list of the 15 main municipalities in this study.

(Figure 4.1.1)

MAIN CITIES IN THE INTERIOR

\begin{tabular}{lcccc}
\hline \multicolumn{1}{c}{ City } & State & Franchise units & Population & Percent \\
\hline Ribeirão Preto & SP & 588 & 666.323 & $0.7 \%$ \\
\hline São José dos Campos & SP & 579 & 688.597 & $0.7 \%$ \\
\hline Sorocaba & SP & 509 & 644.919 & $0.6 \%$ \\
\hline São José do Rio Preto & SP & 467 & 442.548 & $0.6 \%$ \\
\hline Uberlândia & MG & 456 & 662.362 & $0.6 \%$ \\
\hline Maringá & PR & 377 & 397.437 & $0.5 \%$ \\
\hline Jundiaí & SP & 373 & 401.896 & $0.5 \%$ \\
\hline Bauru & SP & 318 & 366.992 & $0.4 \%$ \\
\hline Piracicaba & SP & 309 & 391.449 & $0.4 \%$ \\
\hline
\end{tabular}




\section{(Figure 4.1.1 (conclusion))}

MAIN CITIES IN THE INTERIOR

\begin{tabular}{lcccc}
\hline \multicolumn{1}{c}{ City } & State & Franchise units & Population & Percent \\
\hline Juiz de Fora & MG & 272 & 555.284 & $0.3 \%$ \\
\hline Caxias do Sul & RS & 249 & 474.853 & $0.3 \%$ \\
\hline Imperatriz & MA & 218 & 253.123 & $0.3 \%$ \\
\hline Blumenau & SC & 214 & 338.876 & $0.3 \%$ \\
\hline Cascavel & PR & 212 & 312.778 & $0.3 \%$ \\
\hline Taubaté & SP & 212 & 302.331 & $0.3 \%$ \\
\hline
\end{tabular}

Source: Elaborated by the authors.

The dependent variable used was the number of franchise units in the municipality, whereas the independent variables are the socioeconomic, human resources, and geographical dimensions. The analysis of the socioeconomic dimension included the following: 1. employed persons; 2 . proportion of poor people; and 3. the number of shopping malls in the municipalities. The human resources dimension comprises the following: 1. the percentage of employed persons with a complete degree; 2 . the percentage of employed persons in the service sector; 3 . the percentage of employed persons in the trade sector; and 4. the percentage of self-employed workers. Moreover, the data referring to the geographical dimension correspond to the distance from the municipalities of the state capital. Figure 4.1.2 presents the variables in detail. 


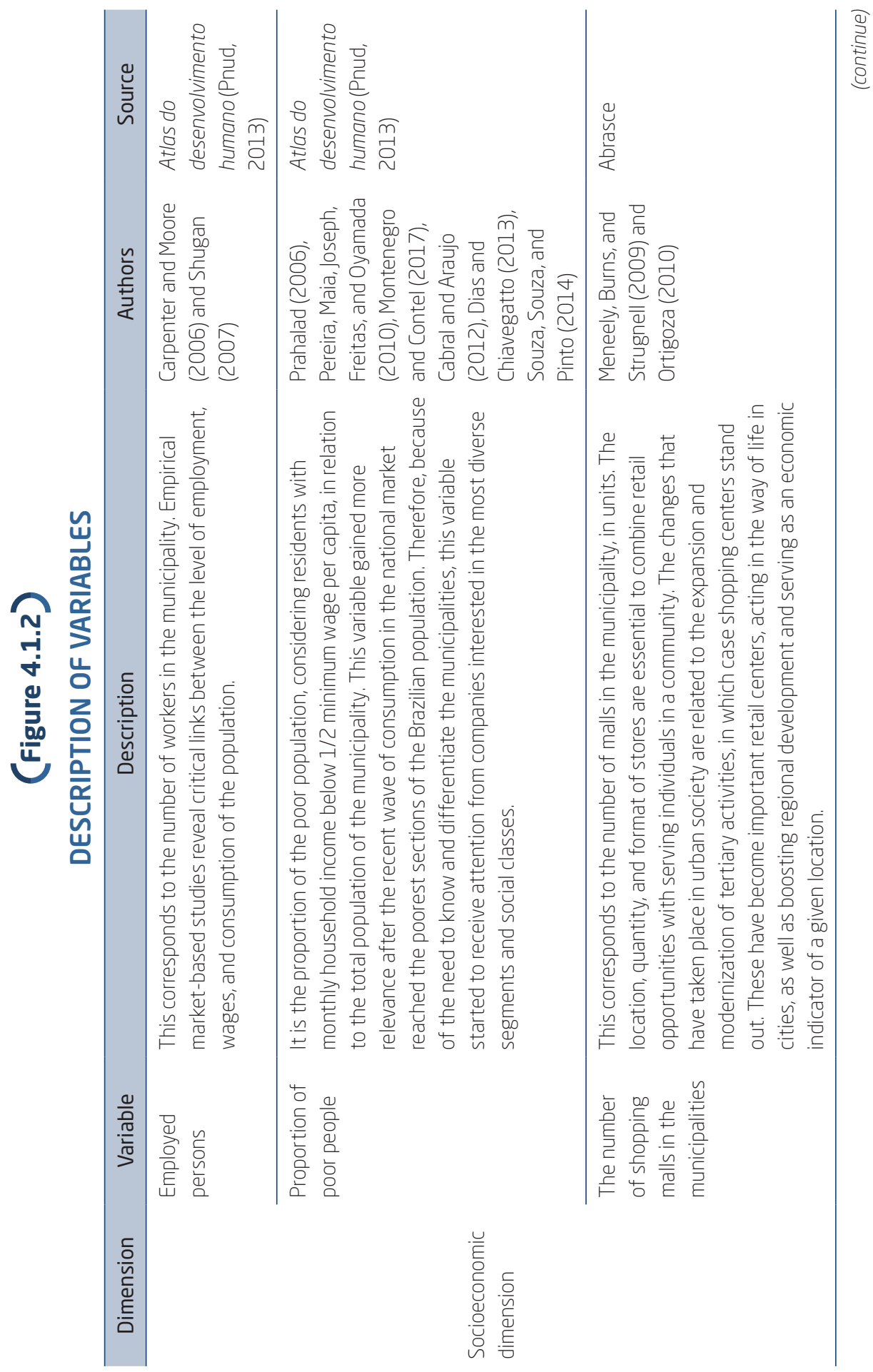




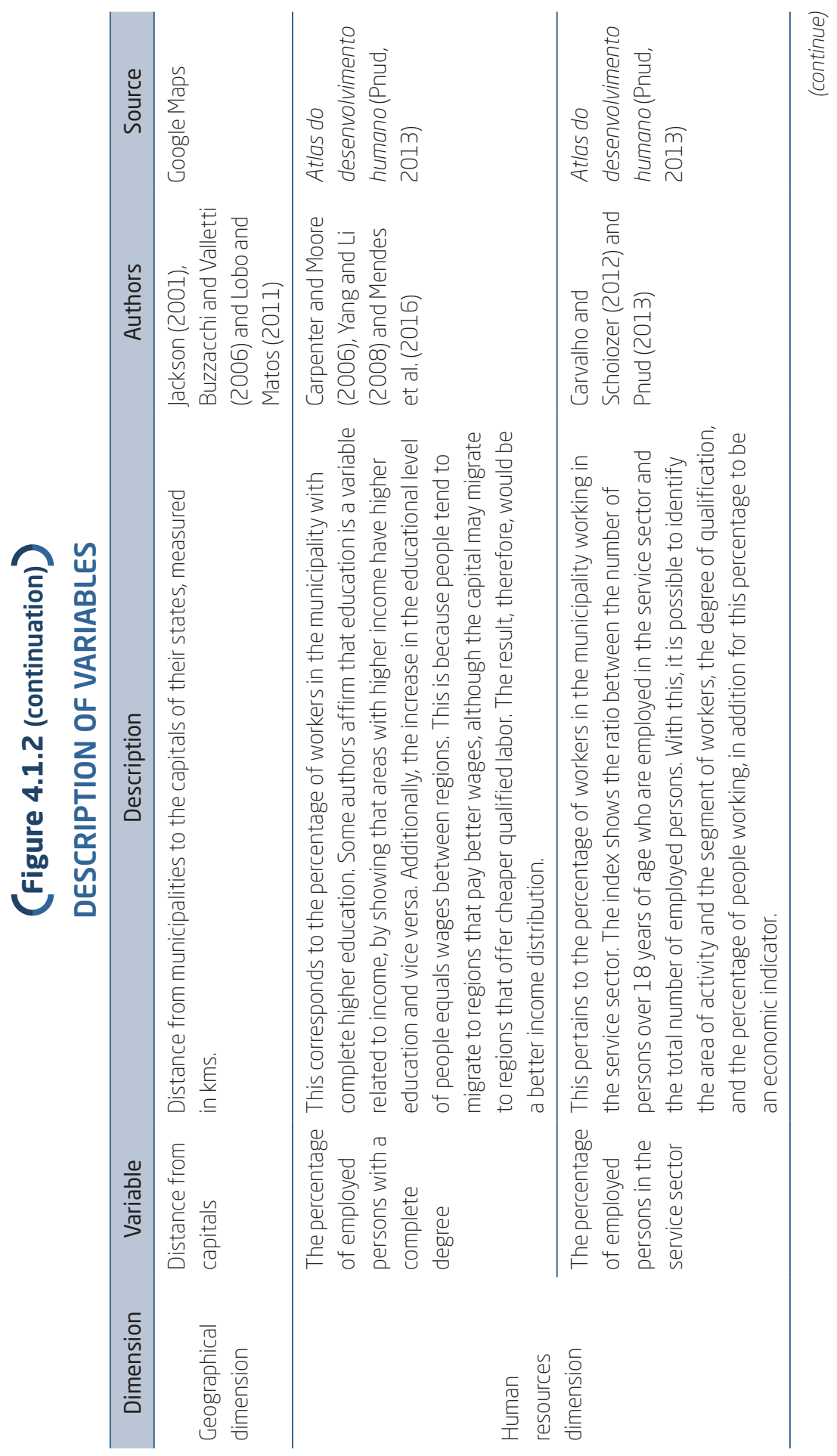




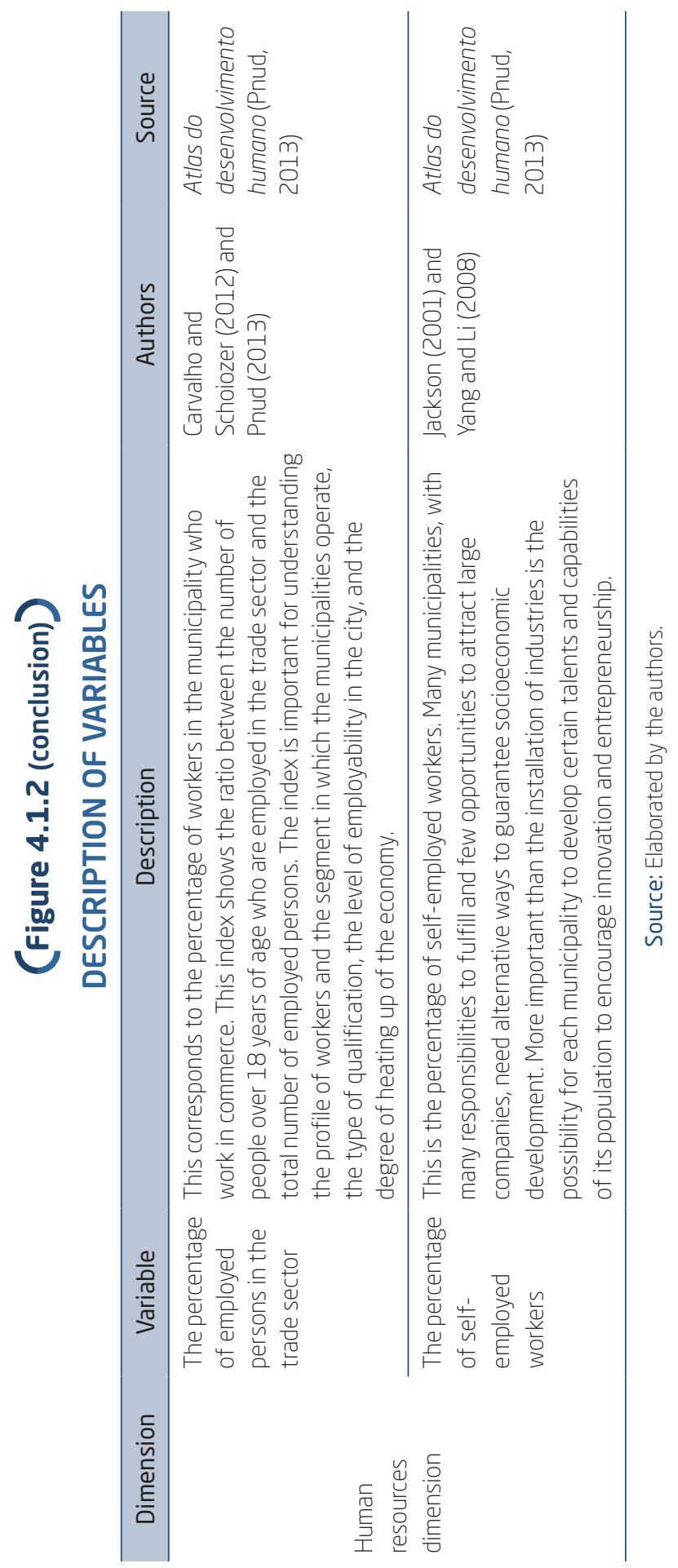


Figure 4.1.3 presents the variables with their corresponding codes that will be used from this point onwards.

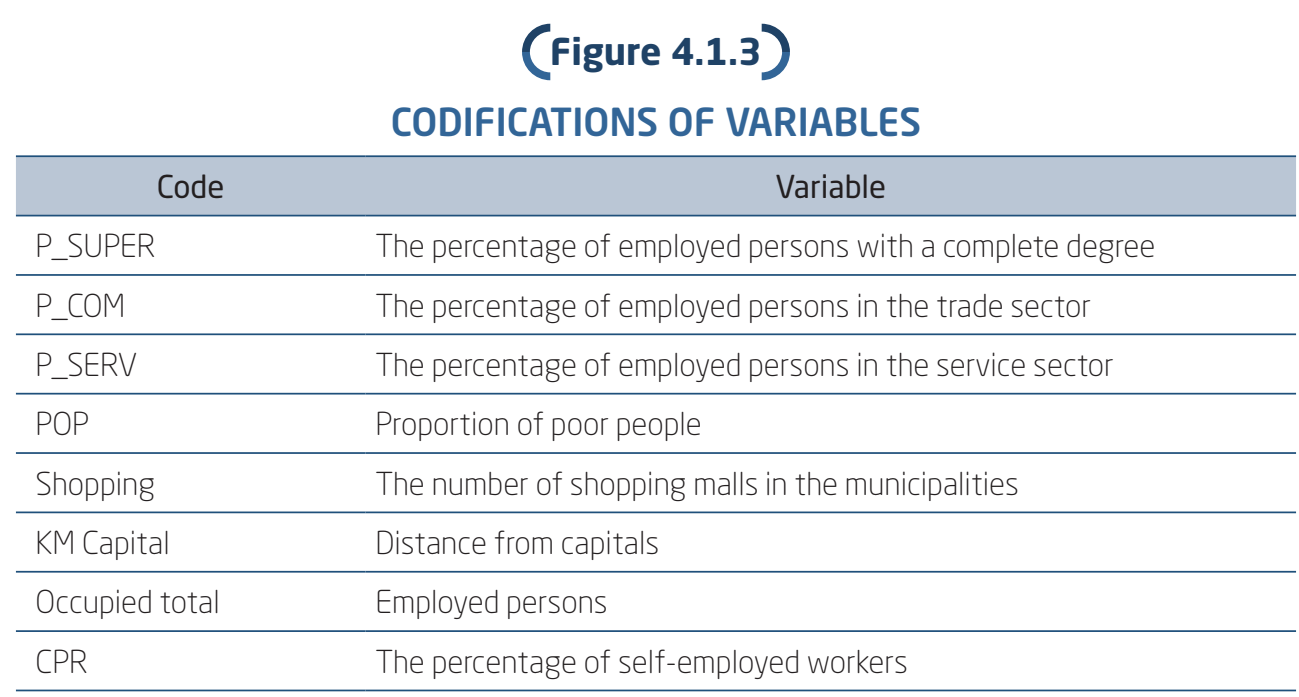

Source: Elaborated by the authors.

Both the variables presented and the results were treated with multivariate statistical techniques of factor analysis and regression.

\section{RESULTS ANALYSIS}

Initially, it was necessary to verify whether it was possible to reduce the variables in socioeconomic, human, and geographical dimensions. For this purpose, a factor analysis was performed using the principal component method with the objective of analyzing which variables have greater explanatory power for the proposed model, synthesizing the data and validating the relationships (Corrar, Paulo, \& Dias, 2012; Flach, Castro, \& Mattos, 2017). Bartlett's sphericity test showed the adequacy of the factor analysis for the data in question, as the p-value was less than the $5 \%$ significance level. Additionally, all communalities were greater than 0.500 (Johnson \& Wichern, 1992). The Varimax orthogonal rotation method was selected as it is most used to produce non-correlated factors and in situations involving human behaviors (Henson \& Roberts, 2006; Johnson \& Wichern, 1992). Figure 5.1 presents the results and shows the rotated factors and the factorial loads distributed for each of them as well as the explained variance of each factor and the total $(77.75 \%)$. 


\section{(Figure 5.1)}

ROTATED COMPONENTS/FACTORS MATRIX

\begin{tabular}{lccc}
\hline & \multicolumn{3}{c}{ Matriz de componente rotativa } \\
\cline { 2 - 4 } & 1- Socioeconomic & 2- Human resources & 3- Geographical \\
\hline Occupied total & 0.94 & 0.26 & -0.06 \\
\hline POP & 0.94 & 0.18 & 0.06 \\
\hline Shopping & 0.92 & 0.13 & -0.07 \\
\hline P_SERV & 0.22 & 0.87 & 0.00 \\
\hline P_SUPER & 0.39 & 0.76 & -0.15 \\
\hline P_COM & 0.09 & 0.64 & 0.45 \\
\hline CPR & -0.05 & -0.64 & 0.50 \\
\hline KM Capital & -0.05 & -0.03 & 0.80 \\
\hline Variância explicada fator & $35.14 \%$ & $28.58 \%$ & $14 \%$ \\
\hline Variância explicada total & $77.75 \%$ & & \\
\hline
\end{tabular}

Source: Elaborated by the authors.

Three factors were obtained: factor 1 (socioeconomic), factor 2 (human resources), and factor 3 (geographical). Factor 1 explains approximately $35 \%$ of the total variance being formed by the proportion of poor people, total number of employed persons, and number of shopping centers in the municipality. The percentage of people employed in services and commerce, percentage of people with higher education employed, and percentage of self-employed workers are the variables that form approximately $28.5 \%$ of the total variance in factor 2 . Finally, factor 3 explains approximately $14 \%$ of the total variance, expressing how far the municipality is in relation to the capital of its state of the federation.

After obtaining the three dimensions, multiple regression analysis was performed to verify the associations proposed in the hypotheses. The regression model is shown in Figure 5.2, with an explanatory power of approximately $91 \%$. The results indicate that the socioeconomic and human resources dimensions are significant for the regression model $(p<0.01)$ and are positively associated with the model. Accordingly, the higher the indexes associated with the socioeconomic and human resources dimension, the greater the number of franchise chains in the municipality. In the 
analysis of standardized coefficients, the socioeconomic dimension presented a Beta of 0.919, that is, a stronger or more important predictor for the number of franchise chains than the human resources dimension, which presented a Beta of 0.259 only. The geographic dimension, in contrast, did not show a significant association.

(Figure 5.2)

REGRESSION MODEL

\begin{tabular}{|c|c|c|c|c|c|}
\hline & $\begin{array}{l}\text { Dependent variable } \\
\text { Franchise units }\end{array}$ & $\begin{array}{l}\text { Standardize } \\
\text { d beta }\end{array}$ & $\mathrm{t}$ & Sig & VIF \\
\hline \multirow{7}{*}{$\begin{array}{l}\text { Independent } \\
\text { variable }\end{array}$} & Constant & & 45.678 & 0.000 & \\
\hline & Socioeconomic & 0.919 & 66.014 & 0.000 & 1.000 \\
\hline & Human resources & 0.259 & 18.641 & 0.000 & 1.000 \\
\hline & Geographical & -0.019 & -1.338 & 0.181 & 1.000 \\
\hline & R2 adjusted & 0.911 & & & \\
\hline & Durbin-Watson & 1.883 & & & \\
\hline & $\mathrm{F}$ & $1,569.02$ & & & \\
\hline
\end{tabular}

Source: Elaborated by the authors.

Three hypotheses were developed in this research. Hypothesis H1, which deals with the indexes linked to the socioeconomic dimension of the municipalities, was confirmed as the factor that represents that the socioeconomic dimension is significantly and positively related to the dependent variable. This hypothesis can be explained by the fact that the higher the professional occupation index of the population, the higher the per capita income of the municipality tends to be, thus generating greater consumption and making the municipality more attractive for franchise chains. Income generation provides a virtuous cycle to the municipality, increasing tax collection and improving the lives of the population and the companies installed there.

Along with hypothesis $\mathrm{H} 1$, hypothesis $\mathrm{H} 2$ was also confirmed as the factor that represents that the dimension of human resources is significantly and positively related to the dependent variable. This dimension goes back to the presence and quality of labor in sectors linked to the activity of franchise chains. Having qualified and specialized labor can be a great differential to attract new business models for the municipalities, mainly in municipalities that are geographically distant from the headquarters of the companies; 
therefore, the expenses with training and agency costs tend to be lower, facilitating business administration. Qualified labor expectedly increases the productivity of workers, which tends to promote individual income and consumption patterns. A virtuous cycle is created because of greater consumption. Companies tend to intensify their production and employ a larger share of workers as well as an increase in new ventures. This generates greater tax revenue for the region, which may increase its spending on social improvements.

In contrast, the result of the factor that represents the geographical dimension was not significant; hence, the hypothesis formulated for the geographical dimension, hypothesis $\mathrm{H} 3$, was not confirmed. This result is in line with previous studies (Moita \& Guerra, 2012; Rodrigues et al., 2015). Based on this result, it is understood that, despite the proximity to the capitals being a logistical facilitator for the units in the interior, this is not a condition for the franchise chains' decision in selecting markets for expansion. This may occur because of other reference locations for supply, such as regional centers or, in the case of border regions between states, the capitals of other states. Additionally, with the advancement of technology, various forms of communication and monitoring have emerged, even with physical distance, which may have further reduced the effect of this dimension.

Hence, the only confirmed hypotheses were $\mathrm{H} 1$ and $\mathrm{H} 2$, which managed to explain the model in $91.1 \%$. H3 did not show adherence to the model. Figure 5.3 presents the synthesis of the results.

\section{(Figure 5.3)}

SUMMARY OF THE RESULT

\begin{tabular}{|c|c|c|}
\hline Hypothesis & Dimensions & Results \\
\hline $\begin{array}{l}\mathrm{H1} \text { : The higher the indexes of the socioeconomic dimension of } \\
\text { the municipalities, the more attractive the municipality is for } \\
\text { franchise chains. }\end{array}$ & Socioeconomic & Confirmed \\
\hline $\begin{array}{l}\mathrm{H} 2 \text { : The higher the human resource dimension indexes, the more } \\
\text { attractive the municipality is for franchise chains. }\end{array}$ & $\begin{array}{l}\text { Human } \\
\text { resources }\end{array}$ & Confirmed \\
\hline $\begin{array}{l}\text { H3: The shorter the distance between the municipality and the } \\
\text { state capital, the more attractive the municipality is for franchise } \\
\text { chains. }\end{array}$ & Geographic & $\begin{array}{l}\text { Not } \\
\text { confirmed }\end{array}$ \\
\hline
\end{tabular}

Source: Elaborated by the authors. 


\section{FINAL CONSIDERATIONS}

This research sought to determine and analyze which characteristics of the institutional environment contribute to a greater presence of franchise chains in markets in the interior of Brazil. To achieve this, with data from 458 Brazilian municipalities, eight variables were analyzed. These were reduced to three dimensions, namely, socioeconomic, human resources, and geographical. The results of this research point out that the positive characteristics related to the socioeconomic and human resources dimensions have an impact on the attractiveness of the municipalities for expanding franchise chains. This is in line with some authors' points on the importance of creating new consumption spaces, such as shopping centers and malls (Carlos, 2001; Silva \& Gonçalves, 2013; Lee et al., 2015), and on the importance of education and qualification of the workforce (Eberhardt \& Lima, 2012; Fonseca et al., 2013; Paschoalino et al., 2016) in the attractiveness of a market for entrepreneurship. However, one dimension did not show adherence to the model in the study. The characteristics of the geographic dimension are not relevant to the attractiveness of municipalities for expanding franchise chains, which is different from what was pointed out by other authors (Moita \& Guerra, 2012; Rodrigues et al., 2015).

The academic contributions of this study refer to the identification of the characteristics of the institutional environment that propelled the expansion of franchise chains in cities in the interior of Brazil. These results show that the attractiveness to the interior markets is because of the formal institutions as understood by the socioeconomic dimension, which is relevant for the identification of the consuming public and the commercial establishment of the franchise chains (Baumol et al., 2007), and the dimension of human resources, determinant for the supply from employees to franchised units (Faller \& Almeida, 2014).

Consequently, contributions are made to studies on the institutional environment for entrepreneurship (Bruton et al., 2010; Khoury \& Prasad, 2015), expansion of franchise chains (Jackson, 2008; Minadeo \& Camargos, 2009; Moita \& Guerra, 2012; Silva et al., 2016), and geographic expansion to regional markets (Barringer \& Greening, 1998; Amin, 1999; Chung et al., 2007; Cordeiro et al., 2017).

Regarding managerial contributions, this research may collaborate with managers of expanding franchise chains in prospecting markets in the interior. The results make it clear that, in the decision-making process, the issue 
of geographic distance in relation to the state capital is not a determining factor for the analysis. In contrast, the analysis must first consider the socioeconomic situation. Municipalities with a larger population and number of employed persons, as well as with a greater number of shopping centers, tend to be more attractive for the establishment of franchised units. Secondly, the decision must also be based on human resources. Municipalities with better-trained workforce are more attractive to franchise chains. However, we emphasize that, because of the results, the hierarchical order of the franchisor's decision-making process must first be socioeconomic factors and then human resources.

The result of the present study also presents managerial contributions to the public managers of the municipalities, in particular the secretaries of economic, social, and education development. Promoting municipal employability and better education for citizens, not only guarantees the discretionary fulfillment expected from the public entity, but is also an important mechanism for attracting new businesses for the creation of a virtuous cycle of regional development. Therefore, public management based on socioeconomic and human resources development, in addition to attracting business, guarantees an increase in the social impact of public management. The limitations of this study are in the profile of the cities studied, which are cities that are state capitals and that belong to metropolitan regions were disregarded, municipalities with less than 50 thousand inhabitants were not considered, and only the distance from the interior city to the capitals was considered as a reference pole.

Suggestions for future studies comprises analyzing the following: 1. the impact of the geographical dimension in relation to the regional hubs closest to the municipalities or regions of greatest influence; 2 . the adherence of franchise chain formats that require less investment, such as microfranchises, in cities with less than 50 thousand inhabitants; 3. the stratification and formation of city clusters according to population size; and 4 . the verification of these models in companies that do not adopt the franchise chain model. 


\section{DESENVOLVIMENTO REGIONAL E AMBIENTE INSTITUCIONAL: EXPANSÃO REGIONAL DAS REDES DE FRANQUIAS NO BRASIL}

\section{RESUMO}

Objetivo: O artigo tem como objetivo analisar a atratividade dos mercados do interior do Brasil para as redes de franquias, considerando as características do ambiente institucional referente às dimensões socioeconômica, geográfica e de recursos humanos.

Originalidade/valor: A interiorização é um tema pouco explorado nas estratégias de crescimento das redes de franquias. Por meio da perspectiva teórica institucional, o artigo contribui para esse debate ao esclarecer e ordenar os fatores de tomada de decisão para a expansão regional das redes de franquias. Da mesma forma, contribui para o desenvolvimento regional ao instigar a gestão municipal para o direcionamento de ações voltadas para desenvolvimento socioeconômico e de recursos humanos.

Design/metodologia/abordagem: Trata-se de um estudo quantitativo, com dados secundários - da Associação Brasileira de Franchising (ABF), Associação Brasileira de Shopping Centers (Abrasce), Instituto Brasileiro de Geografia e Estatística (IBGE) e do site Google Maps) - tanto para a análise da localização das unidades franqueadas como dos municípios. Para a amostra foram selecionados 458 municípios com população acima de 50 mil habitantes. Utilizou-se a técnica estatística de análise fatorial e de análise de regressão múltipla.

Resultados: Os resultados mostram que os fatores socioeconômico e de recursos humanos dos municípios são primordiais para a atratividade das redes de franquias no interior do país. Por sua vez, a distância geográfica do município do interior em relação à capital do estado não apresentou aderência ao modelo explicativo para a atração das redes de franquias.

\section{PALAVRAS-CHAVE}

Redes de franquias. Ambiente institucional. Desenvolvimento regional. Interiorização. Empreendedorismo. 


\section{REFERENCES}

Amin, A. (1999). An institutionalist perspective on regional economic development. International Journal of Urban and Regional Research, 23(2), 365-378.

Associação Brasileira de Franchising. (2016). Relatório de desempenho do franchising do ano de 2015. Recuperado de https://www.abf.com.br/numerosdo-franchising/

Associação Brasileira de Franchising (2017). Inteligência de mercado. Recuperado de https: www.abf.com.br/numeros-do-franchising

Barringer, B. R., \& Greening, D. W. (1998). Growth through geographic expansion: A comparative case study. Journal of Business Venturing, 9026(97), 467-492.

Bathelt, H., \& Gluckler, J. (2014). Institutional change in economic geography. Progress in Human Geography, 38, 340-363.

Baumol, W., Litan, R., \& Schramm, C. J. (2007). Good Capitalism, bad capitalism, and the economics of growth and prosperity. Michigan: Yale University.

Biggart, N. W., \& Beamish, T. D. (2003). The economic sociology of conventions: Habit, custom, practice, and routine. Annual Review of Sociology, 29, 443-464.

Bitti, E. J. S., Aquino, A. C. B., \& Amato, J., Neto (2010). Vectors of influence on the contractual mix: Geographical dispersion vs. automation in Brazilian franchised chains. International Annual EurOMA Conference, Porto, 17. Managing Operations in Services Economies.

Bitti, E. J. S., Fadairo, M., Lanchimba, C., Silva, V.-L. (2016). Spatial strategies in Brazilian franchising: Behavior categories and performance outcome. Anpcont, Ribeirão Preto, 10.

Botomé, S. P., \& Zanelli, J. C. (2011). Is knowledge production in learning and technology the role of post-graduate programs when it comes to training scientists in the country? Revista de Administração Contemporânea, 16(6), 1161-1167.

Bruton, G. D., Ahlstrom, D., \& Li, H. L. (2010). Institutional theory and entrepreneurship: Where are we now and where do we need to move in the future? Entrepreneurship: Theory and Practice, 34(3), 421-440.

Buzzacchi, L., \& Valletti, T. M. (2006). Firm size distribution: Testing the "independent submarkets model" in the Italian motor insurance industry. International Journal of Industrial Organization, 24(4), 809-834. 
Cabral, J., \& Araujo, A. (2015). Estudo sobre a decomposição dos determinantes da variação da pobreza nos estados brasileiros no período 2001 a 2012. Revista de Economia e Sociologia Rural, 53(4), 627-644.

Carlos, A. F. A. (2001). Espaço-tempo na metrópole. São Paulo: Contexto.

Carpenter, J. M., \& Moore, M. (2006). Consumer demographics, store attributes, and retail format choice in the US grocery market. International Journal of Retail \& Distribution Management, 34(6), 434-452. doi:10.11108/ 09590550610667038

Carvalho, C., \& Schiozer, R. F. (2012). Working capital management: A comparative study between the practices of Brazilian and UK Firms. Revista de Administração Contemporânea, 16(4), 518-543.

Castiglione, C., Gorbunova, Y., Infante, D., \& Smirnova, J. (2012). FDI determinants in an idiosyncratic country. A reappraisal over the Russian regions during transition years. Communist and Post-Communist Studies, 45(1-2), 1-10.

Chung, H., Chen, C., \& Hsieh, T. (2007). First geographic expansion of startup firms: Initial size and entry timing effects. Journal of Business Research, 60, 388-395.

Cordeiro, R. A., Barbone, D., Cruz, R. C., Francisco, E. de R. (2017). Uso de sistema de informação geográfica na gestão do marketing mix: O caso de uma rede de calçados femininos. Future Journal, 9(1), 95-114.

Corrar, L. J., Paulo, E., \& Dias J. M., Filho (Coords.) (2012). Análise multivariada para cursos de Administração, Ciências Contábeis e Economia (4a ed.). São Paulo: Atlas.

Creswell, J. W. (2010). Projeto de pesquisa: Métodos qualitativo, quantitativo e misto (3a ed.). Porto Alegre: Penso.

Cruz, B. P. A. (2014). Classe C e o fenômeno social TV no Brasil. Revista Administração em Diálogo, 17(3), 106-128.

Cunha, O., Abida, R., Woods, D., Sonneveld, S., \& Carrera, H. (2015). Capturing retail growth in Brazil's rising interior. BCG, 1(1), 1-15.

Dan, M. C., \& Goia, D. I. (2018). Entrepreneurship and regional development. A bibliometric analysis. Proceedings of the International Conference on Business Excellence, Bucharest, Romania.

Data Popular (2014). Dossie interior do Brasil: Dimensionamento, características e oportunidades. São Paulo: Instituto Data Popular.

Dias, A., \& Chiavegatto, P. (2013). How to include the characteristics of the districts of the Municipality of São Paulo in epidemiologic studies: An income inequality analysis using the propensity score matching approach. Saúde Soc., 22(4), 1145-1153. 
Dias, J. P. S., \& Hemais, M. W. (2015). Consumidores de baixa renda e compras on-line: Receios em consumir pela internet. Revista de Gestão, 22(1), $115-132$.

Eberhardt, P. H. de C., \& Lima, J. F. de. (2012). Evolução e estágio do desenvolvimento econômico regional: O caso das regiões do Paraná. Desenvolvimento Regional em Debate, 2(1), 189-203.

Faller, L. P., \& Almeida, M. I. R. de. (2014). Planejamento por cenários: Preparando pequenas empresas do varejo de móveis planejados para um futuro competitivo. Revista de Administração, 1 (49), 171-187.

Félix, R. D. C., \& Farah, M. F., Júnior (2013). Entrepreneurship and development in the cities of Paraná. Revista Brasileira de Planejamento e Desenvolvimento, 2(2), 104-117.

Flach, L., Castro, J. K., \& Mattos, L. K. D. (2017). Avaliação de desempenho financeiro de empresas brasileiras de energia a partir da análise fatorial e árvore de decisão. Revista Eletrônica de Estratégia e Negócios, 10(1), 201-225.

Fonseca, F., Beltrão, R. E., \& Prado, O. (2013). Avaliando a capacidade de governo: Reflexões sobre a experiência do Prêmio "Municípios que Fazem Render Mais” (2010 e 2011). Revista de Administração Pública, 47(1), 249-272.

Fontenele, R. E. S., Moura, H. J., \& Leocadio, A. L. (2011). Capital humano, empreendedorismo e desenvolvimento: Evidências empíricas nos municípios do Ceará. Revista de Administração Mackenzie, 12(5), 182-208.

Haddad, P. (2009). Capitais intangíveis e desenvolvimento regional. Revista de Economia, 35(3), 119-146.

Henson, R., \& Roberts, J. (2006). Use of exploratory analysis in published research: Common errors and some comments on improved practice. Educational and Psychological Measurement, 66, 393-416. doi:10.1177/0013 164405282485

Hessels, J., \& Terjesen, S. (2010). Resource dependency and institutional theory perspectives on direct and indirect export choices. Small Business Economics, 34(2), 203-220.

Instituto Brasileiro de Geografia e Estatística (2014). Censo demográfico 2010. Recuperado de https://www.ibge.gov.br/estatisticas-novoportal/sociais/ populacao/9662-censo-demografico-2010.html? \&t=downloads

Jackson, C. A. (2001). Model of spatial patterns across local retail property markets in Great Britain. Urban Studies, 38(9), 1445-1471.

Jackson, S. E. (2008). Reaching for value making growth make sense for retail and franchise businesses. Journal of Business Strategy, 29(3), 48-50. 
Johnson, R. A., \& Wichern, D. W. (1992). Applied Multivariate Statistical Analysis. Englewood Cliffs: Prentice Hall.

Kamakura, W., \& Mazzon, J. A. (2016). Critérios de estratificação e comparação de classificadores socioeconômicos no Brasil. Revista de Administração de Empresas, 56(1), 55-70.

Khoury, T. A., Cuervo-Cazurra, A., \& Dau, L. A. (2014). Institutional insiders and outsiders: The response of domestic and foreign investors to the quality of intellectual property rights protection. Global Strategy Journal, 4, 200-220.

Khoury, T. A., \& Prasad, A. (2015) Entrepreneurship amid concurrent institutional constraints in less developed countries. Business \& Society, 55(7), 927-933.

Lee, I., Lee, C., Yoo, S., \& Choi, M. (2015). A decision-making model of social shopping in franchising: Assessing collaboration strategies. International Journal of Information Technology \& Decision Making, 14(2), 95-420.

Lobo, C., \& Matos, R. (2011). Migrações e a dispersão espacial da população nas regiões de influência das principais metrópoles brasileiras. Revista Brasileira de Estudos de População, 28(1), 81-101.

Lopes, H. C. (2013) Instituições e crescimento econômico: Os modelos teóricos de Thorstein Veblen e Douglass North. Revista de Economia Política, 33(133), 619-637.

Melo, P. L. R., Borini, F. M., \& Ogasavara, M. H. (2019). Latin America franchise chains internationalization: The impact of institutional environment. Thunderbird International Business Review, 61(2), 217-228. doi:10.1002/tie. 21975

Melo, P. L. de R., Borini, F. M., Oliveira, M. de M., Jr., \& Parente, R. C. (2015). Internationalization of Brazilian franchise chains: A Comparative Study. Revista de Administração de Empresas, 55(3), 258-272.

Meneely, L., Strugnell, C., \& Burns, A. (2009). Age associated changes in older consumers retail behavior. International Journal of Retail \& Distribution Management, 37(12), 1041-1056.

Minadeo, R., \& Camargos, M. A. de (2009). Fusões e aquisições no varejo alimentar: Uma análise das estratégias de entrada e de crescimento do Carrefour e Wal-Mart no mercado brasileiro. Revista de Ciências da Administração, $11(24), 102-135$.

Moita, R. M. S., \& Guerra, A. (2012). Entradas e bandeiras: Estratégia de interiorização das cadeias de fast-food. Revista de Administração de Empresas, 52(1), 85-99. 
Montenegro, M., \& Contel, F. (2017). Financeirização do território e novos nexos entre pobreza e consumo na metrópole de São Paulo. Revista Latinoamericana de Estudios Urbano Regionales, 43(130), 115-139.

Muller, S. (2016). A progress review of entrepreneurship and regional development: What are the remaining gaps? European Planning Studies, 24(6), 1133-1158.

North, D. C. (1991). Institutions. Journal of Economic Perspectives, 5(1), 97-112.

Ortigoza, S. A. G. (2010). Paisagens do consumo: São Paulo, Lisboa, Dubai e Seul. São Paulo: Editora Unesp.

Paschoalino, P. A. T., Caldarelli, C. E., \& Camara, M. R. G. da. (2016). Capital humano e desenvolvimento no estado do Paraná entre 2000 e 2001: Uma análise espacial. Desenvolvimento Regional em Debate, 6(3), 193-215.

Peredo, A. M., \& McLean, M. (2013). Indigenous development and the cultural captivity of entrepreneurship. Business \& Society, 52, 592-620.

Pereira, B., Maia, J., Joseph, L., Freitas, A., \& Oyamada, G. (2010). Pobreza e desigualdade de renda entre famílias da zona rural de Mato Grosso de 2004 a 2006. Revista Ciência Agronômica, 41 (4), 536-545.

Portal do Franchising (2015). Interiorização das franquias avança e ABF e Sebrae investem em capacitação de empreendedores. Recuperado de http:// www.portaldofranchising.com.br/noticias/interiorizacao-das-franquiasavanca-e-abf-e-sebrae-investem-em-capacitacao-de-empreendedores/

Prahalad, C. K. (2006). The fortune at the bottom of the pyramid: Eradicating poverty through profits. New Jersey: Pearson Education.

Prahalad, C. K. (2012). Bottom of the pyramid as a source of breakthrough innovations. Journal of Product Innovation Management, 29(1), 6-12.

Programa das Nações Unidas para o Desenvolvimento (2013). Atlas do desenvolvimento humano. Recuperado de http://www.atlasbrasil.org.br/2013/pt/ o_atlas/idhm

Rodrigues, P. C. T., Bezerra, E. L. de A., \& Cavalcante, N. F. (2015). O paradoxo das distâncias psíquica, cultural e geográfica. Faces Journal, 14(1), 49-79.

Schwens, C., Eiche, J., \& Kabst, R. (2011). The moderating impact of informal institutional distance and formal institutional risk on SME entry mode choice. Journal of Management Studies, 48(2), 330-351.

Shugan, S. M. (2007). Does good marketing cause bad unemployment? Marketing Science, 26(1), 1-17. 
Silva, H., Monte-Mór, R. L., \& Barbieri, A. F. (2012). Demografia do consumo urbano: Um estudo sobre a geração de resíduos sólidos domiciliares no município de Belo Horizonte. Revista Brasileira de Estudos de População, 29(2), 421-449.

Silva, J. B., \& Gonçalves, T. E. (2013). Urbanização e produção da cidade: Shopping centers na dinâmica de novas centralidades em Fortaleza-CE. Geosul, 27(53), 63-88.

Souza, T. S., Souza, E. R., \& Pinto, L. W. (2014). The evolution of mortality by homicide in the State of Bahia in the period from 1996 to 2010. Ciência E Saúde Coletiva, 19(6), 1889-1900.

Steer, L., \& Sen, K. (2010). Formal and informal institutions in a transition economy: The case of Vietnam. World Development, 38, 1603-1615.

Valdez, M. E., \& Richardson, J. (2013). Institutional Determinants of MacroLevel Entrepreneurship. Entrepreneurship Theory and Practice, (973), 1149-1175.

Welter, F., \& Smallbone, S. (2010). The embeddedness of women's entrepreneurship in a transition context. In C. Brush, A. Bruin, E. Gatewood, \& C. Henry (Eds.), Women entrepreneurs and the global environment for growth: A research perspective (pp. 96-117). Cheltenham: Edward Elgar.

Yang, J. Y., \& Li, J. (2008). The development of entrepreneurship in China. Asia Pacific Journal of Management, 25(2), 335-359.

Xavier, T. R., Inácio, R. O., Wittmann, M. L., \& Kern, J. (2013). O estudo do desenvolvimento regional: Uma análise da produção científica internacional e dos "hot-topics". Gestão \& Regionalidade, 29(87), 19-31.

\section{AUTHOR NOTES}

Pedro L. R. Melo, Ph.D. from the Faculty of Economics, Administration, Accounting and Actuaries (FEA), University of São Paulo (USP); Renata T. Delgado, master from the Postgraduate Program in Administration, Paulista University (Unip); Victor S. Corrêa, Ph.D. from the Postgraduate Program in Administration, Pontifical Catholic University of Minas Gerais (PUC Minas); Felipe M. Borini, Ph.D. from the Faculty of Economics, Administration, Accounting and Actuaries (FEA), University of São Paulo (USP).

Pedro L. R. Melo is now full professor at the Postgraduate Program in Administration of Unip; Renata T. Delgado is now professor at the Department of Technological Degree in Logistics of Unip; Victor S. Corrêa is now full professor at the Postgraduate Program in Administration of Unip; Felipe M. Borini is now associate professor at the FEA-USP.

Correspondence concerning this article should be addressed to Pedro L. R. Melo, Rua Doutor Bacelar, 1212, 4º andar, Vila Clementino, São Paulo, São Paulo, Brasil, CEP 04026-002.

E-mail: pedro.melo@docente.unip.br 
Pedro L. R. Melo, Renata T. Delgado, Victor S. Corrêa, Felipe M. Borini

\section{EDITORIAL BOARD}

Editor-in-chief

Gilberto Perez

Associated Editor

Márcia Mota Darós

Technical support

Vitória Batista Santos Silva

\section{EDITORIAL PRODUCTION}

Publishing coordination

Jéssica Dametta

Editorial intern

Paula Di Sessa Vavlis

Language editor

Daniel de Almeida Leão
Layout designer

Emap

Graphic designer Libro 